\title{
EFFECT OF BIOLOGICAL NITRIFICATION INHIBITOR ON NITROGEN FIXATION AND EMISSION REDUCTION IN STRAW AND DAIRY MANURE COMPOSTING
}

\author{
REN, L. T. ${ }^{1,3,4}-$ ZHANG, X. ${ }^{1}-$ YANG, L. $^{2 *}-$ HAO, B. ${ }^{4}-$ SHAO, Q. Q. ${ }^{1}-$ ZHANG, C. J. ${ }^{3}$ \\ ${ }^{I}$ Anhui Science and Technology University, Bengbu, Anhui, China \\ ${ }^{2}$ China Institute of Standardization, Beijing, China \\ ${ }^{3}$ Anhui Laimujia Biotechnology Co., Ltd., Bengbu, Anhui, China \\ ${ }^{4}$ Benbu Ludu Biotechnology Co., Ltd., Bengbu, China \\ *Corresponding author \\ (Received 11 $1^{\text {th }}$ Apr 2019; accepted $4^{\text {th }}$ Jul 2019)
}

\begin{abstract}
The purpose of this study was to analyze the effect of biological nitrification inhibitor MHPP on nitrogen fixation and emission reduction for straw and dairy manure composting. During the period from May to September in China, the engineering large-scale composting was performed with dark box sampling was conducted to take composting gas sample which was studied gas chromatography. The result indicated that, in relation to the control, to which no MHPP extract solution was added, the addition of $0.2 \%, 0.4 \%, 0.6 \%$ and $0.8 \%$ MHPP extract solutions reduced the methane emission by $44.52 \%$, $56.56 \%, 61.93 \%, 59.59 \%$, the $\mathrm{N}_{2} \mathrm{O}$ emission by $36.24 \%, 39.49 \%, 62.39$ and $55.81 \%$, and the $\mathrm{NH}_{3}$ emission by $23.72 \%, 65.61 \%, 65.40 \%$ and $72.61 \%$; after the addition of biological nitrification inhibitor, the composting process slowed down; the ammonium nitrogen content was high while the nitrate nitrogen content was low; all substances thoroughly decomposed in the end. Moreover, the final ammonium nitrogen content was higher in all cases when compared to the control. The results showed that the addition of $0.6 \%$ MHPP extract solution worked the best for nitrogen fixation and emission reduction and thus is appropriate to be used extensively in production activities.
\end{abstract}

Keywords: crop residue composting, $\mathrm{N}_{2} \mathrm{O}, \mathrm{NH}_{3}, \mathrm{CH}_{4}$, biological nitrification inhibitor

\section{Introduction}

With the increase of grain output in China, the straw resources grew constantly to more than a billion tons; furthermore, the mushrooming of livestock and poultry feeding industry in China produced a lot of waste. Both are considered environmental difficulties of rural areas and agriculture. As one of the effective approaches of fertilization against non-point source pollution in the planting and breeding industry, high-temperature aerobic composting has aroused wide concern all over the world, and turning into a research focus in the field of eco-friendliness and environmental protection.

High-temperature composting technology that may bring about non-point source pollution is widely recognized in agriculture, but researchers argued that the emission of some harmful gases and greenhouse gases, including $\mathrm{NH}_{3}, \mathrm{CH}_{4}$ and $\mathrm{N}_{2} \mathrm{O}$, may cause secondary pollution to a certain extent during high-temperature composting. During composting, the degradation and nitrification and denitrification of organic nitrogen produces a certain amount of $\mathrm{NH}_{3}$ and $\mathrm{N}_{2} \mathrm{O}$; the emission of $\mathrm{N}$-containing gas result in a nitrogen loss that range from $16 \%$ to $76 \%$, which not only impairs the quality of compost, but may also lead to environmental pollution (Wu et al., 2012). Moreover, ammonia is not only an important factor affecting acid rain, but is also a key component 
of odor substances in composting plants; the Emission Standard for Odor Pollutants (GB14554-93) issued by China in 1993 announces ammonia as the primary odor pollutant. According to the IPPC report 2014, the 100a greenhouse effect produced by $\mathrm{N}_{2} \mathrm{O}$ and $\mathrm{CH}_{4}$ was 25 and 298 times that of $\mathrm{CO}_{2}$, respectively (IPCC, 2014). From this perspective, the emission of ammonia and greenhouse gases during composting not only adversely reduced the land use value, but also resulted in odor pollution, acid rain, greenhouse effect and other new ecological and environmental problems; in addition, they may harm human and animal health. Hence, along with the growing sophistication of composting technology, how to reduce nitrogen loss and greenhouse gas emission during composting has become a research focus.

Adding chemical additives like peat, calcium superphosphate, ferric chloride, zeolite and clay (Yang et al., 2005) is considered one of the effective ways to emission realize nitrogen fixation and emission reduction. Liu et al. (2015) found that adding 3\% bamboo acetic acid to compost materials helped to reduce greenhouse gas emission and improve compost quality. Works of Ren et al. (2008) showed that the nitrogen fixation rate reached $73.1-97 \%$ with the addition of phosphate and magnesium hydroxide, etc. during composting; Jiang et al. (2018) found that $\mathrm{NH}_{3}$ volatilization was significantly reduced during aerobic degradation of pig manure and corn straws by adding calcium phosphate and phosphoric acid.

Through the research on generation and regulation of odor in pig manure composting, Luo et al. (2012) found that the addition of calcium phosphate during pig manure composting not only reduced the compost $\mathrm{pH}$ and the concentration of volatile $\mathrm{NH}_{3}$, but also facilitated the transformation of $\mathrm{NH}_{4}{ }^{+}-\mathrm{N}$ into other forms of nitrogen, thereby improving nitrogen retention. Lin et al. (2008), Weng et al. (2012) and Ren et al. (2009) found that the addition of calcium phosphate helped to reduce $\mathrm{NH}_{3}$ emission during composting and thus retain nitrogen. Jiang et al. (2016) found in his study that the addition of nitrification inhibitor dicyandiamide (DCD) based on the use of acidic nitrogen fixer reduced the total greenhouse gas emission by $78 \%$ and $\mathrm{NH}_{3}$ emission by $53 \%$. The added nitrification inhibitors (NIs) are a generic term of a class of chemical substances that inhibit nitrification reaction by inhibiting the activity of nitrifying bacteria, thereby reducing nitrogen loss. DCD is widely used in Europe and America as a NI, but it is seldom used for composting. Li et al. (2008) and Ji et al. (2011) found that DCD reduced $\mathrm{CH}_{4}$ and $\mathrm{N}_{2} \mathrm{O}$ emission of rice and wheat by over 20\%. Luo et al. (2013) and Jiang et al. (2016) also confirmed that the addition of DCD during composting of pig manure and straws remarkably reduced $\mathrm{N}_{2} \mathrm{O}$ emission. Chen et al. (2017) tried to use calcium superphosphate with DCD for sludge composting and achieved remarkable effect: The nitrogen losses were reduced by $13 \%$, and the greenhouse gas emissions by $74.8 \%$.

Although nitrification inhibitors are significantly effective in reducing $\mathrm{N}_{2} \mathrm{O}$ emission, they are not extensively used in production due to their high cost and toxicity; hence, some researchers shifted their attention to lower-cost biological nitrification inhibitors. Zakir et al. (2008) identified the MHPP (methyl 3-(4-hydroxyphenyl) propionate) as a biological nitrification inhibitor from sorghum root exudate to inhibit nitrification in soil. Wei et al. and Zhu et al. (2015) studied the molecular mechanism of MHPP, but there are few reports on the application of MHPP in composting. In this study, MHPP was used for composting and is compared with DCD, the most commonly used nitrification inhibitor, to systematically study the effect of this new nitrogen fixation and emission reduction conditioner on the rule of nitrogen gas and greenhouse gas emission during fermentation of straws and dairy manure; its purpose is to provide a theoretical 
basis for the selection of nitrogen fixation and emission reduction conditioner for straw and dairy manure composting.

\section{Materials and methods}

\section{Test materials}

The wheat straws for the test were taken from the Fengyang Plantation of Anhui Science and Technology University and was smashed to $8-10 \mathrm{~cm}$ in size. The fresh dairy manure was taken from the cattle farm of Fucheng Town, Fengyang County, Anhui Province. The initial properties of straws and dung before the test are shown in Table 1 . The $2^{\text {nd }}$ and $4^{\text {th }}$ row used for calculate $\mathrm{C} / \mathrm{N}$ ratio. The calcium superphosphate was purchased from Bengbu Tianyi Biological Agents Co., Ltd., and its effective component was defined as $\mathrm{P}_{2} \mathrm{O}_{5}(\geq 18 \%)$; the dicyandiamide was analytically pure.

Table 1. Physical and chemical characters of raw materials

\begin{tabular}{c|c|c|c|c|c|c|c}
\hline Materials & $\begin{array}{c}\text { Moisture } \\
\text { content } \\
(\boldsymbol{\%})\end{array}$ & $\begin{array}{c}\text { Total organic } \\
\text { carbon mass } \\
\text { fraction }(\mathbf{g} / \mathbf{k g})\end{array}$ & $\mathbf{p H}$ & $\begin{array}{c}\text { Total } \\
\text { nitrogen } \\
(\mathbf{g} / \mathbf{k g})\end{array}$ & $\begin{array}{c}\text { Total } \\
\text { phosphorous } \\
(\mathbf{g} / \mathbf{k g})\end{array}$ & $\begin{array}{c}\text { Total } \\
\text { potassium } \\
(\mathbf{g} / \mathbf{k g})\end{array}$ & $\mathbf{C / N}$ \\
\hline Dairy manure & $62.62 \pm 0.55$ & $398.76 \pm 0.34$ & $7.85 \pm 0.08$ & $24.86 \pm 0.12$ & $30.32 \pm 0.32$ & $11.17 \pm 0.18$ & 16.04 \\
Wheat Straw & $12.65 \pm 0.23$ & $489.23 \pm 0.38$ & $7.21 \pm 0.03$ & $8.92 \pm 0.13$ & $3.28 \pm 0.41$ & $79.34 \pm 0.29$ & 54.82 \\
\hline
\end{tabular}

Values in average \pm standard deviation $(n=3)$

\section{Test design}

This test was performed at the plantation test field of Anhui Science and Technology University in China between May and September 2017. It was performed on a cement floor, and the composting treatment design was as follows: Fresh weight of dairy manure: straw $=1.5: 1$, and the treatment details are shown in Table 2. the MHPP leaching liquor was added once every seven days; the calcium superphosphate was added only once, and "blank" indicates no calcium superphosphate was added; refer to Table 2 for details. $7.5 \mathrm{t}$ of dairy manure and $3 \mathrm{t}$ of straws were prepared; the straws were smashed into $8-10 \mathrm{~cm}$ in size and mixed with the dairy manure with spray water to a proportion of approx. 65\%; the mixture was divided evenly into five piles $(4 \mathrm{t}$ per pile); the temperature was raised to above $65{ }^{\circ} \mathrm{C}$, at which manual turning was conducted with the help of weed-grasping machine every 7days. The compost temperature was determined on a daily basis (9:00 am) during composting, and samples were taken $\mathrm{d} 0, \mathrm{~d} 5, \mathrm{~d} 10, \mathrm{~d} 15, \mathrm{~d} 20, \mathrm{~d} 25, \mathrm{~d} 30, \mathrm{~d} 35, \mathrm{~d} 40$ and $\mathrm{d} 45$, respectively. The composting was ceased when the germination rate of Chinese cabbage seeds reached over $90 \%$.

\section{Test items and methods}

Samples of greenhouse gases $\left(\mathrm{CH}_{4}, \mathrm{~N}_{2} \mathrm{O}\right.$, and $\left.\mathrm{CO}_{2}\right)$ were taken with static dark boxes customized from Fenglu Building Materials Store in Xuanwu District, Nanjing; the sampling case covered with aluminum foil (PVC, $\mathrm{L} \times \mathrm{W} \times \mathrm{H}=50 \mathrm{~cm} \times 50 \mathrm{~cm} \times 50 \mathrm{~cm}$ ) was placed over the pile; we measure thecircumference of the pile when we took gas sample. We calculate area by circumference. The pile is protected from disturbance and 
sealed with water; set it aside for 30 min before the sampling was started, and gas was collected with a $50 \mathrm{ml}$ syringe with a three-phase valve every $10 \mathrm{~min}$ ( 3 cycles in total); the sample test was finished within $24 \mathrm{~h}$; where the test was not finished within $24 \mathrm{~h}$, the gas was collected with a $100 \mathrm{ml}$ sampling bag. $\mathrm{CH}_{4}$ and $\mathrm{N}_{2} \mathrm{O}$ were analyzed with the gas chromatograph (Agilient 4890, the USA) at the same time, and the $\mathrm{CH}_{4}$ and $\mathrm{N}_{2} \mathrm{O}$ concentrations were determined respectively with FID (Flame Ionization Detector) and ECD (Electron Capture Detector). The ammonia sample was taken with dark box through gas collection and ventilation, and the gas was sampled with a sampling pump; $10 \mathrm{ml}$ of sulfuric acid absorbent was put in the bubble sampler, where its flow rate was 1.2 L per minute; the sampling process lasted for $10 \mathrm{~min}$. Determination was performed with Nessler's Reagent. Weed-grasping machine used HTZC-600 (Henan Hengtong Machinery Co., Ltd.), sampling pump used E-Switch-MRO292-1.2L (Shanghai Shenyuan Scientific Instruments Co., Ltd.) (Photo 1).

Table 2. Addition proportion of materials in each compost treatment

\begin{tabular}{c|c|c|c}
\hline \multirow{2}{*}{ Treatment } & $\begin{array}{l}\text { Raw materials } \\
\text { (fresh weight) }\end{array}$ & \multicolumn{2}{|c}{ Percentage of additives to raw materials mass/\% } \\
\cline { 3 - 4 } & Calcium superphosphate & Nitrification inhibitor \\
\hline \multirow{2}{*}{$\mathrm{CK}$} & $\begin{array}{l}\text { Dairy manure: } \\
\text { Straws = 1.5:1 }\end{array}$ & $0 \%$ & 0 \\
$\mathrm{~T} 1$ & $\begin{array}{l}\text { Dairy manure: } \\
\text { Straws = 1.5:1 }\end{array}$ & $0 \%$ & $1 \% \mathrm{DCD}$ \\
$\mathrm{T} 2$ & $\begin{array}{l}\text { Dairy manure: } \\
\text { Straws = 1.5:1 }\end{array}$ & $2 \%$ & $1 \% \mathrm{DCD}$ \\
$\mathrm{T} 3$ & $\begin{array}{l}\text { Dairy manure: } \\
\text { Straws = 1.5:1 } \\
\text { Dairy manure: } \\
\text { T4traws = 1.5:1 }\end{array}$ & $0 \%$ & $1 \% \mathrm{MHPP}$ \\
\hline
\end{tabular}
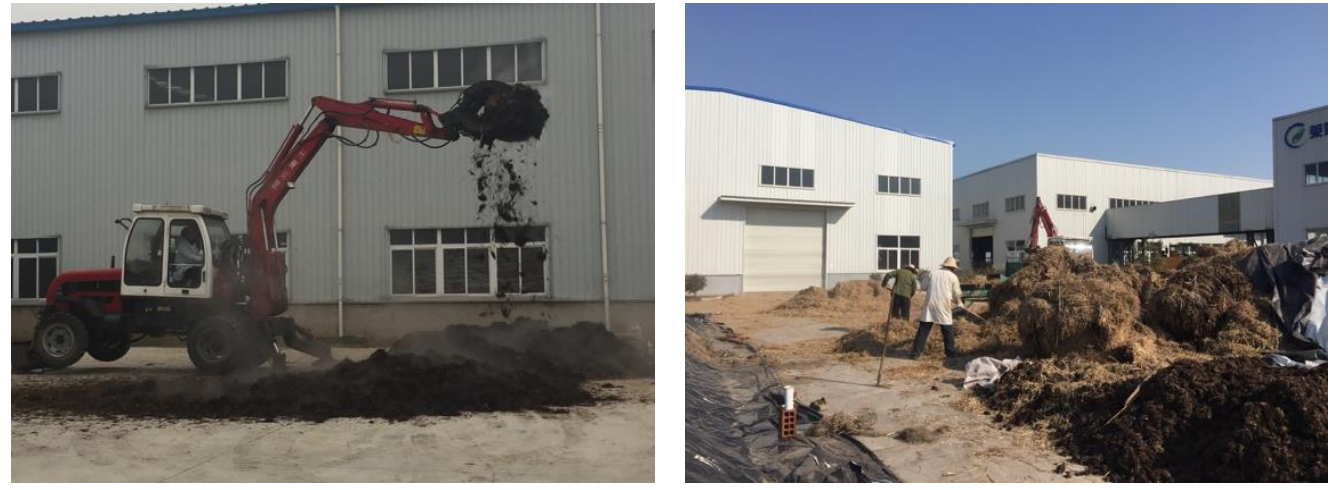

Photo 1. The equipment we used and experimental picture

\section{Results}

\section{Effect of addition of MHPP addition on the variation of compost temperature}

Temperature is an important indicator indicating of whether the organic matters are degraded rapidly during composting of straws and dairy manure. The treatment-specific temperature fluctuations during composting for this test are shown in Figure 1. In each 
treatment cycle, the mesophilic microorganisms degraded the soluble and easily degradable organic matters in straws and dairy manure at low temperature in the initial phase of composting, where a lot of heat was released, resulting in the quick rise of compost temperature within a short time; with the decrease of available organic matters, the activity intensity of microorganisms decreased progressively, and the compost temperature dropped gradually; in this process, the compost became thoroughly decomposed.

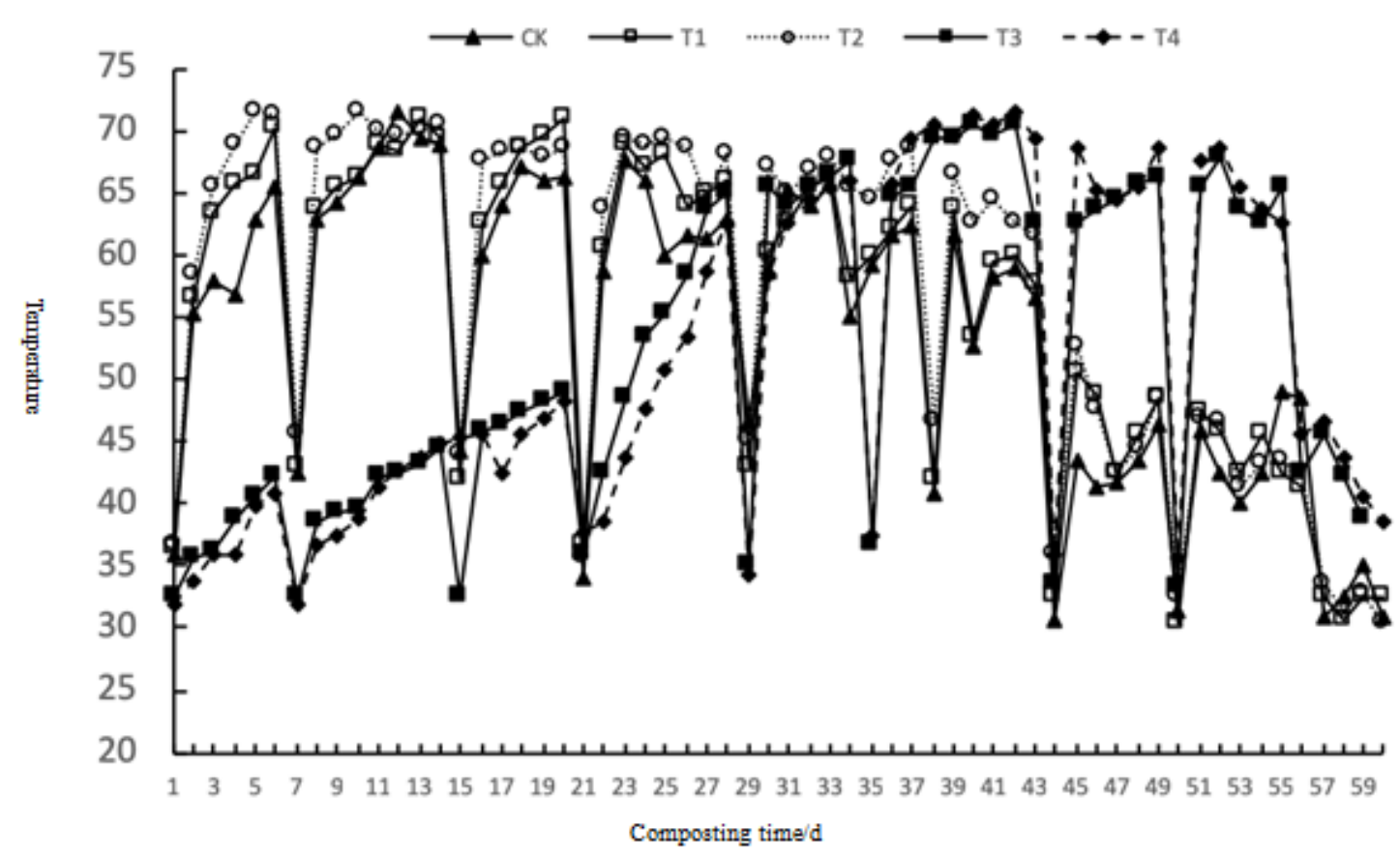

Figure 1. Change of temperature during composting period

Control and treatment 1 and 2 got into the high temperature period $\left(>50{ }^{\circ} \mathrm{C}\right)$ on $\mathrm{d} 2$ and went above $70{ }^{\circ} \mathrm{C}$ on $\mathrm{d} 5$; the heat-up effect was extremely obvious and higher than that of control; the high temperature lasted for approx. one month before the temperature starting to drop. The temperatures of Treatment 3 and Treatment 4 went up slowly at the beginning of composting, and reached $50{ }^{\circ} \mathrm{C}$ on $\mathrm{d} 24$; this may be because that the microbial activity was probably inhibited with the obvious inhibiting effect of MHPP; despite the slow rise, the high temperature lasted for approx. one month later. The high temperature period $\left(>50{ }^{\circ} \mathrm{C}\right)$ of each treatment lasted for about one month, which was much longer than 5 days for innocuous treatment according to the national regulations of China; this helps to kill pathogenic microorganisms and pathogenic eggs during composting, thus assuring the innocuous treatment of composting.

\section{Effect of the addition of MHPP addition on emission of methane as a greenhouse gas from compost}

$\mathrm{CH}_{4}$ is a greenhouse gas produced by methane bacteria from the simple organic matters like methylamines, methyl alcohols, methyl acids and other carbon-containing compounds, as well as carbon dioxide and hydrogen in straws and dairy manure in pile. As shown in Figure 2, the methane emission peaks of all the four treatments occurred at 
early stage of composting; the quick rise of temperature in early stage stimulated microorganisms to degrade organic matters efficiently, which consumed a lot of oxygen; as a result, the excessively low locally soluble oxygen content facilitated the production of high content of $\mathrm{CH}_{4}$. As the composting progressed, the organic carbon available in straws and dairy manure was consumed progressively, and the microbial activity decreased, and the $\mathrm{CH}_{4}$ emission rate went down gradually; in the end, the degradation of organic matters stopped, so $\mathrm{CH}_{4}$ emission was hardly detected.

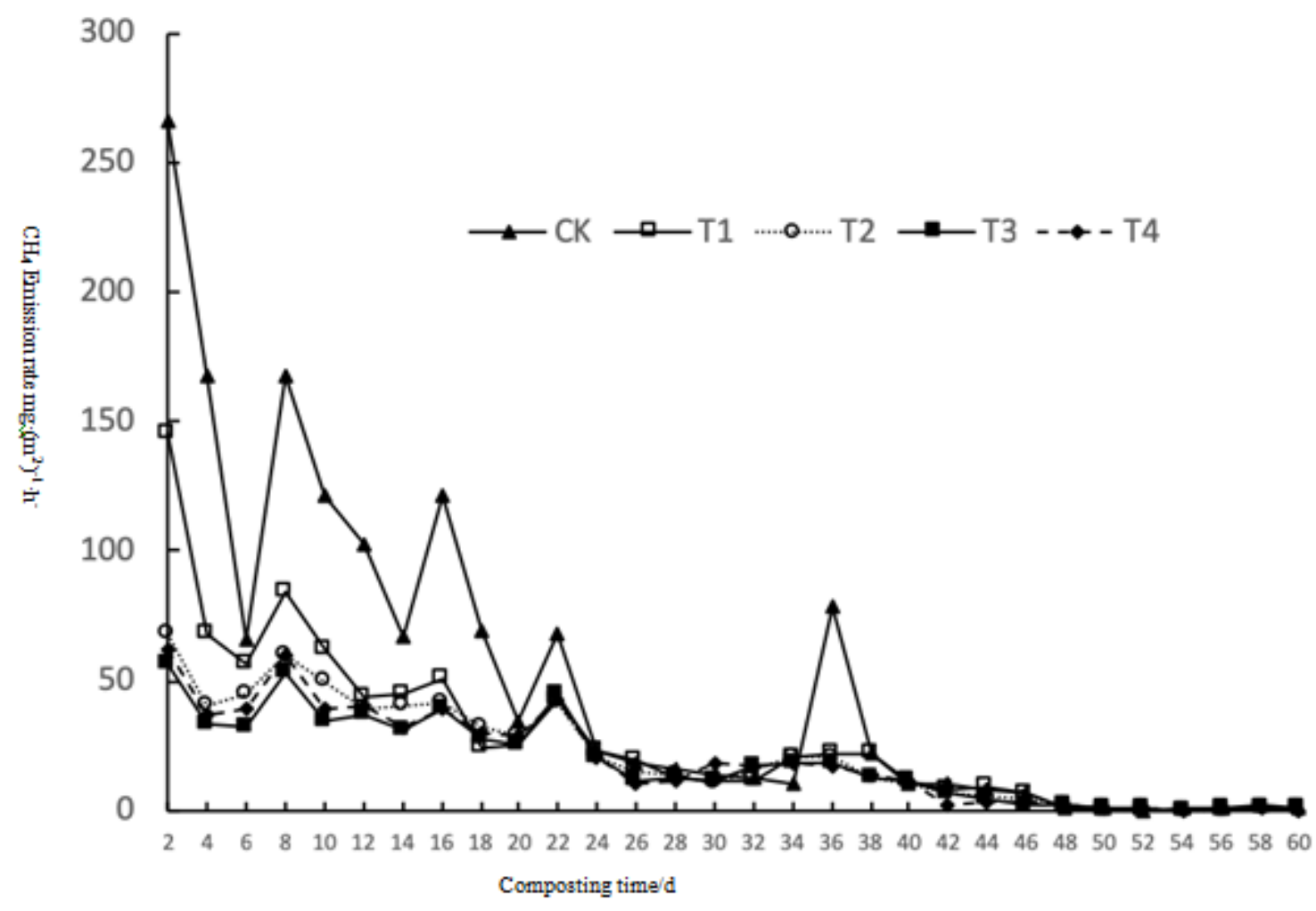

Figure 2. $\mathrm{CH}_{4}$ emission rate during composting

The $\mathrm{CH}_{4}$ emission peak was detected in $\mathrm{CK}$ treatment at the very beginning, where the mean emission rate was $49.52 \mathrm{mg} / \mathrm{m}^{2} / \mathrm{h}$; the $\mathrm{T} 1-\mathrm{T} 4$ drainage rates were lower than that of CK, indicating that the addition of DCD and MHPP played a remarkable role in reducing emission from the composting of dairy manure and straws; measurement and calculation showed that the cumulative emission from CK was approx. $71.30 \mathrm{~g} / \mathrm{m}^{2}$, while the emission from T1-T4 was $39.56 \mathrm{~g} / \mathrm{m}^{2}, 30.98 \mathrm{~g} / \mathrm{m}^{2}, 27.15 \mathrm{~g} / \mathrm{m}^{2}$ and $28.81 \mathrm{~g} / \mathrm{m}^{2}$, which indicated the emission was reduced by $44.52 \%, 56.56 \%, 61.93 \%$ and $59.59 \%$, respectively. It is observed that the effect of DCD to which calcium superphosphate was added was more obvious, while the addition of calcium superphosphate exhibited insignificant effect on MHPP emission reduction.

That the addition of calcium superphosphate and DCD help to reduce methane emission echoed the report of Luo et al.(2012), The main reason for such reduction is because that the sulfate ions in calcium superphosphate help to reduce the pile $\mathrm{pH}$, which further inhibited the activity of methane bacteria, thereby realizing in the reduction of methane emission. In addition, since sulfate reducing bacteria reduce sulfate radicals into $\mathrm{S}^{2-}$ with acetic acid, lactic acid and hydrogen ions as electron 
donors and with sulfate radicals as electron acceptors during composting, methane bacteria could finish their own biochemical metabolism; a competitive relation existed in between; additionally, $\mathrm{S}^{2-}$ had certain toxic effect on methane bacteria. However, the rate of emission reduction was not enhanced after the addition of calcium superphosphate to MHPP; the principal reason may be that the acidic calcium superphosphate brought about no promoter action in the ammonium nitrogen environment of MHPP.

The addition of calcium superphosphate reduced the carbon-nitrogen ratio, indicating that the addition of calcium superphosphate facilitated the ingestion of affecting component in microorganisms during composting, thus facilitating the microbial metabolism and the decomposition of organic matters.

\section{Effect of the addition of MHPP on emission of $\mathrm{N}_{2} \mathrm{O}$ as a greenhouse gas from compost}

Ammonium nitrogen was continuously transformed into nitrate nitrogen during composting, and $\mathrm{N}_{2} \mathrm{O}$ was frequently produced in this nitrification process; in addition, $\mathrm{N}_{2} \mathrm{O}$ was generated during the denitrification from nitrate nitrogen to ammonium nitrogen. As can be seen from $\mathrm{CK}$ in Figure 3, the low temperature and adequate oxygen in early stage of traditional composting promoted the generation of abundant $\mathrm{N}_{2} \mathrm{O}$ at compost surface, which was consistent with the studies of Hao et al. (2001) and Sommer et al. (2000). In the thorough decomposition period, the substantive production of nitrate nitrogen brought about denitrification that produced $\mathrm{N}_{2} \mathrm{O}$. The nitrates and nitrites generated in areas where there was plenty of oxygen were carried by pile turning into the anaerobic zone, where denitrification occurred while some $\mathrm{N}_{2} \mathrm{O}$ was emitted, which was echoed the studies of Thompson et al. (2004) and Fukumoto et al. (2003); the nitrification process oxidized ammonia into hydroxylamine with the help of catalytic effect of ammonia monooxygenase on ammonia oxidizing bacteria and ammoniaoxidizing archaea; hydroxylamine produced $\mathrm{NO}_{2}{ }^{-}$under the action of hydroxylamine oxidoreductase, while $\mathrm{NO}_{2}{ }^{-}$was the key source of $\mathrm{N}_{2} \mathrm{O}$, so the major way to reduce $\mathrm{N}_{2} \mathrm{O}$ should be the alleviation of nitration and denitrification reaction; there were two key ways of blockage: First, the production of initial $\mathrm{NH}_{3}$ could be reduced by changing the pile $\mathrm{pH}$; second, the ammonia monooxygenase or hydroxylamine reductase could be inhibited through DCD nitrification inhibitors.

In the present study, calcium superphosphate was used to improve the pile $\mathrm{pH}$ by reducing it below 6.5 , thereby considerably reducing the emission of $\mathrm{NH}_{3}$, the precursor of $\mathrm{N}_{2} \mathrm{O}$. As can be seen from Figure 3, the addition of DCD, calcium superphosphate and MHPP to T1-T4 caused the $\mathrm{N}_{2} \mathrm{O}$ amount to drop significantly; the $\mathrm{N}_{2} \mathrm{O}$ emission from T1, T2, T3 and T4 were $36.24 \%, 39.49 \%, 62.39 \%$ and $55.81 \%$ respectively less than the total $\mathrm{N}_{2} \mathrm{O}$ emission from CK. The MHPP worked better in emission reduction; the effect of DCD with calcium superphosphate added was more obvious, while the effect of MHPP with calcium superphosphate added in emission reduction was inferior to the effect of MHPP without calcium superphosphate added.

\section{Effect of MHPP addition on emission of harmful gas $\mathrm{NH}_{3}$ from composting}

As shown in Figure 4, a lot of ammonia was emitted in early stage of CK during traditional composting because the temperature rise in early stage of composting resulted in constant degradation of nitrogenous organic compounds, which produced 
abundant ammonium nitrogen; in the stationary phase, the reduction of degradable nitrogen and the transformation of ammonium nitrogen into nitrate nitrogen or organic nitrogen enabled ammonia to effectively fix nitrogen in the form of ammonium phosphate when calcium superphosphate is added.

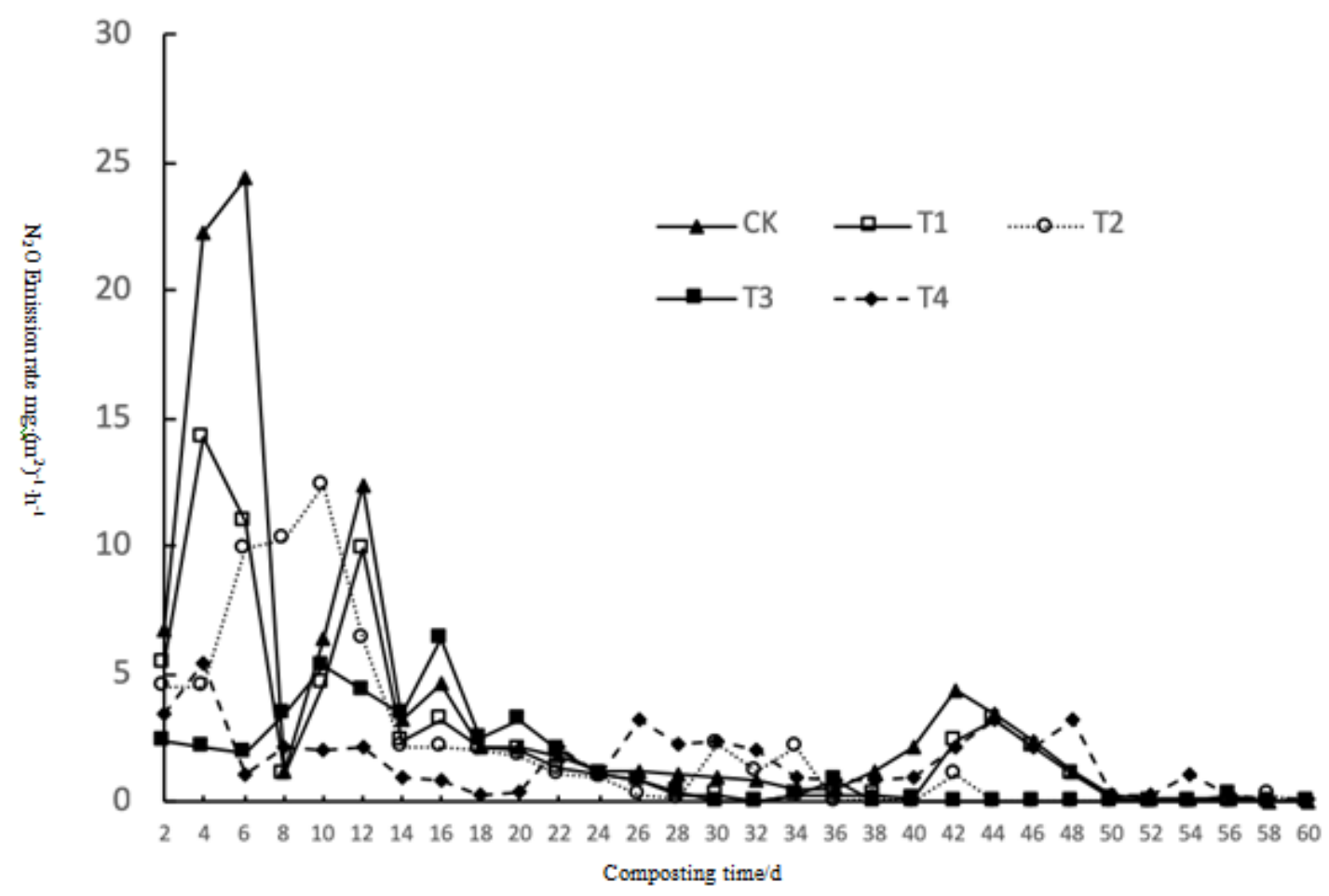

Figure 3. $\mathrm{N}_{2} \mathrm{O}$ emission rate during composting

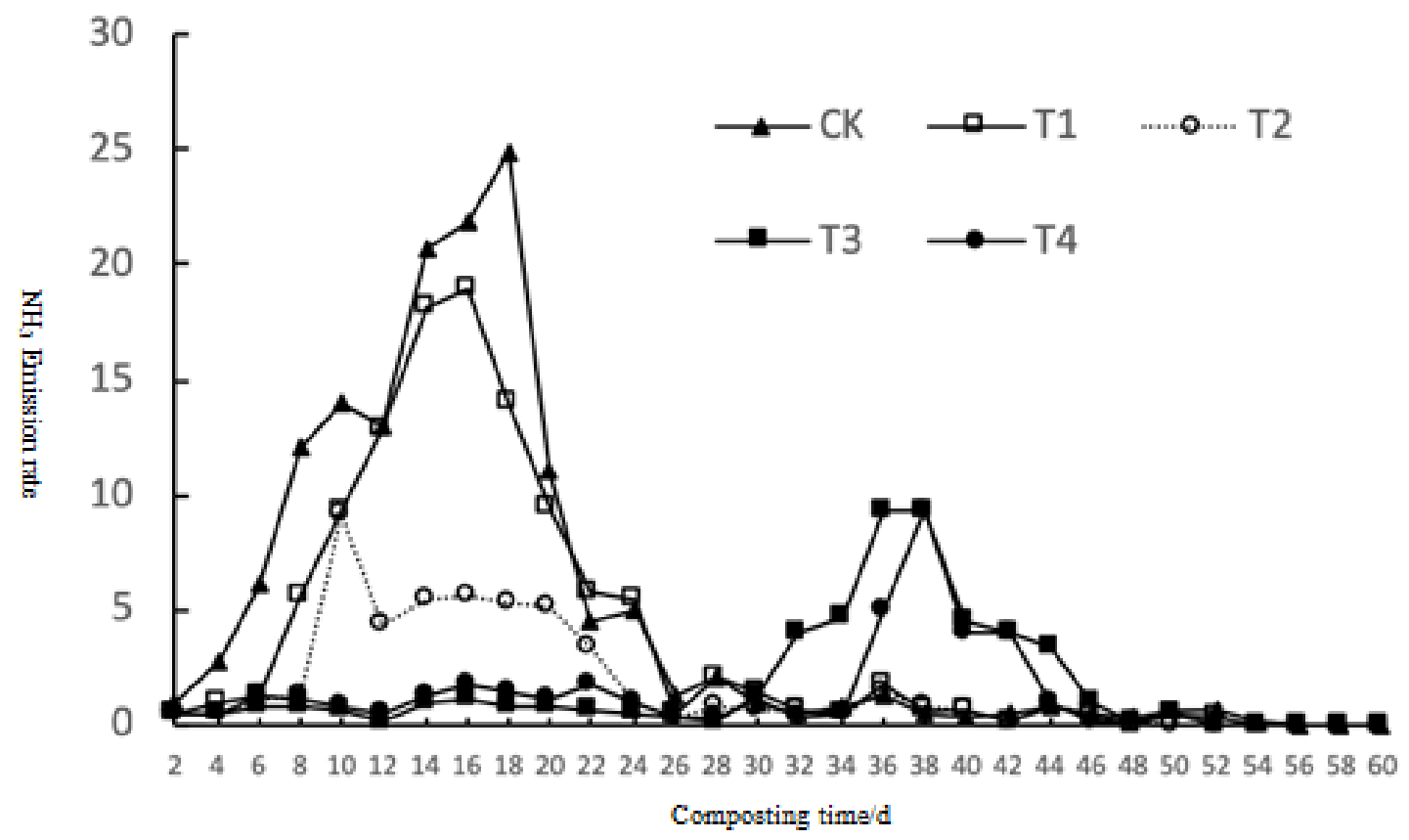

Figure 4. $\mathrm{NH}_{3}$ emission rate during composting 
The $\mathrm{NH}_{3}$ emission during composting is shown in Figure 4, where the $\mathrm{NH}_{3}$ emission of all the four treatments peaked during high-temperature period; nitrogenous organic compounds were substantively decomposed during high-temperature period, which produced a lot of ammonia. The ammonia emission was extremely low in the early and late stages of composting when temperatures were relatively low; throughout the stages, the emission of ammonia was reduced by T1-T4 by $23.72 \%, 65.61 \%, 65.40 \%$ and $72.61 \%$ respectively as compared with the control; the dominant mechanism was as follows: The acidic calcium superphosphate regulated the $\mathrm{pH}$ during composting below 6.5 ; as a result, $\mathrm{N}$ existed in the form of $\mathrm{NH}_{4}+$, which went against the release of ammonia; in such a case, it existed in the form of ammonium acid phosphate or ammonium sulfate. The study performed by $\mathrm{Li}$ et al. (2008) demonstrated that the addition of calcium superphosphate reduced the ammonia emission from pig manure and rice straws by $39.39 \%$; the value in the present study is greater than in that study, because nitrification inhibitor was added in the present study in addition to calcium superphosphate.

\section{Variation of ammonium nitrogen $\left(\mathrm{NH}_{4}^{+}-\mathrm{N}\right)$ content and nitrate nitrogen $\left(\mathrm{NO}_{3}^{-}-\mathrm{N}\right)$ contents}

Ammonium nitrogen $\left(\mathrm{NH}_{4}{ }^{+}-\mathrm{N}\right)$ and nitrate nitrogen $\left(\mathrm{NO}_{3}{ }^{-} \mathrm{N}\right)$ content variation is considered an important indicator for determination of nitrogen circulation during composting; refer to Figure 5 for the variation pattern during composting; with the constant degradation of organic matters at early stage of composting, the composting of each treatment reached the high-temperature period, when microbial activity intensified, and the $\mathrm{NH}_{4}{ }^{+}-\mathrm{N}$ content of each treatment rose continually; it is observed that the $\mathrm{NH}_{4}{ }^{+}-$ $\mathrm{N}$ from $\mathrm{CK}$ in traditional composting dropped rapidly after 28 days, while the $\mathrm{NO}_{3}{ }^{-}-\mathrm{N}$ of $\mathrm{CK}$ shot up after the same period, which indicated that the $\mathrm{NH}_{4}{ }^{+}-\mathrm{N}$ of control was turning into $\mathrm{NO}_{3}{ }^{-} \mathrm{N}$, and that the decrease was greater than the increase; and that the decrease was greater than the increase; this demonstrated that part of the nitrogen was emitted from the pile in the form of gas, namely $\mathrm{NH}_{3}$ and $\mathrm{N}_{2} \mathrm{O}$. Where calcium superphosphate, DCD and MHPP were added to T1-T4, the $\mathrm{NH}_{4}{ }^{+}-\mathrm{N}$ of T1 slightly decreased in approx. 28 days, while that of T2, T3 and T4 did not went down significantly, which indicated the combination of calcium superphosphate and DCD alleviated the transformation and decomposition of $\mathrm{NH}_{4}{ }^{+}-\mathrm{N}$; only the $\mathrm{NO}_{3}-\mathrm{N}$ of $\mathrm{T} 1$ slightly increased after 28 days while that of T2-T4 exhibited no significant rise, which demonstrated that calcium superphosphate, DCD and MHPP prevented $\mathrm{NH}_{4}{ }^{+}-\mathrm{N}$ turning into $\mathrm{NO}_{3}{ }^{-} \mathrm{N}$, because DCD and MHPP inhibited the activity of nitrifying bacteria, thereby inhibiting or event preventing the nitrification in compost.

\section{Physico-chemical and material decomposition indicators}

Germination percentage is an important indicator for evaluation of compost decomposition; it is generally agreed that thorough decomposition is realized when GI > 80\%; "thorough decomposition" means the application of fertilizer to crops bring about no secondary decomposition and lead to no adverse effects. In the present study, the germination percentage was higher than $96 \%$, much higher than $80 \%$; the reason why the germination percentage did not reach $100 \%$ may be because that it was impossible for any seeds to realize a germination percentage of $100 \%$. A compost conductivity greater than $4 \mathrm{~ms} / \mathrm{cm}$ may cause physiological damage to field crops, so 
compost conductivity is also known as an important indicator of compost safety; as shown in Table 3, the conductivity dropped from 3.19-3.294 ms/cm to 0.96-1.89 $\mathrm{ms} / \mathrm{cm}$, which represented the compliance with safety requirements.
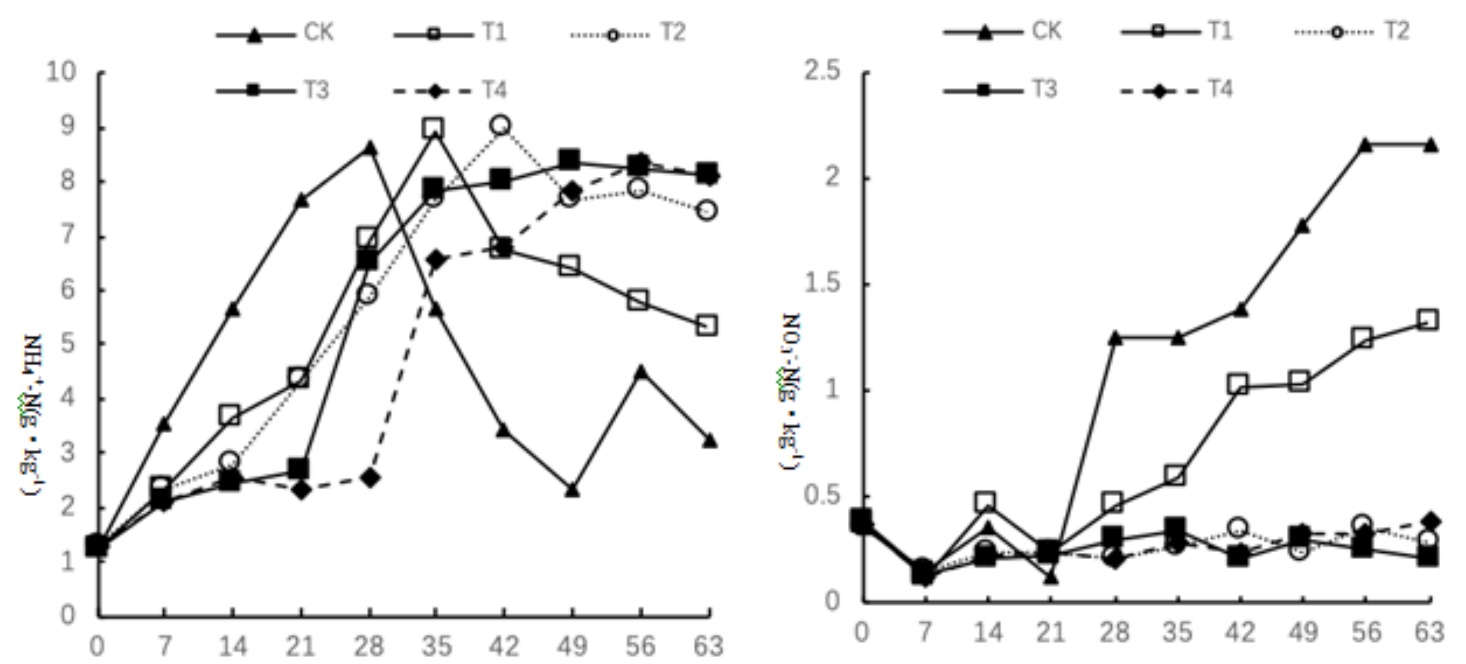

Composting time/d

Figure 5. Changes of $\mathrm{NH}_{4}{ }^{+}-\mathrm{N}$ and $\mathrm{NO}_{3}{ }^{-}-\mathrm{N}$ content

Table 3. Chemical and physical characters and maturity index of composting

\begin{tabular}{c|c|c|c|c|c}
\hline Treatment & $\begin{array}{c}\text { Compost } \\
\text { Period }\end{array}$ & C/N & $\mathrm{pH}$ & Germination\% & $\begin{array}{c}\text { Electric conductivity } \\
\text { EC/(ms } \cdot \mathrm{cm}-1)\end{array}$ \\
\hline \multirow{2}{*}{$\mathrm{CK}$} & Start & $25.79 \mathrm{a}$ & $7.85 \pm 0.08 \mathrm{a}$ & $28.50 \pm 6.75 \mathrm{a}$ & $3.25 \pm 0.15 \mathrm{a}$ \\
& End & $10.23 \mathrm{a}$ & $7.46 \pm 0.12 \mathrm{~b}$ & $97.75 \pm 0.25 \mathrm{ab}$ & $0.96 \pm 0.08 \mathrm{~d}$ \\
$\mathrm{~T} 1$ & Start & $25.79 \mathrm{a}$ & $7.81 \pm 0.03 \mathrm{a}$ & $22.75 \pm 7.75 \mathrm{~d}$ & $3.29 \pm 0.21 \mathrm{a}$ \\
& End & $10.09 \mathrm{~b}$ & $7.86 \pm 0.32 \mathrm{a}$ & $98.75 \pm 0.50 \mathrm{a}$ & $1.22 \pm 0.03 \mathrm{c}$ \\
$\mathrm{T} 2$ & Start & $25.79 \mathrm{a}$ & $7.79 \pm 0.06 \mathrm{a}$ & $23.25 \pm 3.50 \mathrm{c}$ & $3.32 \pm 0.05 \mathrm{a}$ \\
& End & $9.87 \mathrm{c}$ & $7.16 \pm 0.09 \mathrm{c}$ & $96.25 \pm 0.25 \mathrm{~b}$ & $1.68 \pm 0.08 \mathrm{~b}$ \\
$\mathrm{~T} 3$ & Start & $25.79 \mathrm{a}$ & $7.19 \pm 0.03 \mathrm{~b}$ & $28.50 \pm 7.75 \mathrm{a}$ & $3.23 \pm 0.04 \mathrm{a}$ \\
& End & $10.13 \mathrm{a}$ & $7.09 \pm 0.09 \mathrm{~d}$ & $98.75 \pm 0.75 \mathrm{a}$ & $1.86 \pm 0.02 \mathrm{a}$ \\
$\mathrm{T} 4$ & Start & $25.79 \mathrm{a}$ & $6.85 \pm 0.08 \mathrm{c}$ & $25.50 \pm 5.75 \mathrm{~b}$ & $3.19 \pm 0.03 \mathrm{a}$ \\
& End & $10.02 \mathrm{~b}$ & $7.12 \pm 0.09 \mathrm{c}$ & $97.75 \pm 0.25 \mathrm{ab}$ & $1.89 \pm 0.05 \mathrm{a}$ \\
\hline
\end{tabular}

Lower-case letters indicate significant differences at $\mathrm{p}<5 \%$ level

\section{Discussion}

Chemically synthetic nitrification inhibitors principally include dicyandiamide (DCD), nitrapyrin and DMPP, which have been brought into production; however, these chemically synthetic inhibitors are not extensively used in agricultural production due to their high costs, their instable properties in different climates and soils (Li et al., 2008) and certain problems to be solved.

$\mathrm{DCD}$, as a common nitrification inhibitor, can effectively inhibit the oxidation of ammonia, alleviate the leaching loss of nitrate nitrogen and the nitrogen loss resulting from denitrification, and improve the utilization of nitrogenous fertilizer (Moir et al., 
2010); however, there were some drawbacks with the application of DCD: The application rate of DCD had to reach $15-30 \mathrm{~kg}$ per $\mathrm{Mu}$ (666.7 square meters) so as to achieve inhibiting effect; DCD was extremely mobile in soil since it was easily soluble in water (Jacinthe et al., 1992), and the resulting spatial separation from ammonium nitrogen may impair the inhibiting effect; in the case of intense rainfall or soil with poor water retention capacity, leaching loss of DCD may frequently occur; the repeated application of DCD may cause the degradation rate to increase, thus reducing the halftime. Certain studies reported that the application of DCD may bring about toxic effects on crops (Xmb et al., 2003). The application of nitrapyrin increases the yield by $7 \%$, reduces the nitrogen loss by $16 \%$, and reduces the greenhouse gases emission by $51 \%$ (Woil et al., 2004); however, since nitrapyrin is a chlorinated organic matter, its longterm application may adversely affect the environment. Furthermore, nitrapyrin is prone to volatilization and photolysis, which makes it unsuitable for surface fertilization; moreover, the risk of corrosion and explosion makes it difficult to apply and keep this substance. Other studies showed that nitrapyrin exhibited certain toxicity that brought about curved and sallow leaves etc. in some plants (Maftoun et al.1981).

In contrast, the biological nitrification inhibitor MHPP produced through induction in ammonium nitrogen environment is a biological product produced by plants that are not harmful to the environment; since neither toxic nor side effect was detected during the test, MHPP is expected to be extensively generalized in composting and agricultural production. However, this substance is still under study, and the way to turn it into stable powder for extensive popularization is one of the important aspects of next step of research.

\section{Conclusion}

1. The combination of calcium superphosphate and MHPP did not cause the composting of straws and dairy manure to slow down, but improved the final compost quality; the ultimate germination percentage of each treatment was $97.5 \%, 98 \%, 98 \%$ and $97.5 \%$, respectively.

2. The addition of calcium superphosphate and MHPP reduced the nitrogen oxide and ammonia emission during composting; the most appropriate content of MHPP was found to be $0.6 \%$, where the emission of $\mathrm{NH}_{3}, \mathrm{~N}_{2} \mathrm{O}$ and $\mathrm{CH}_{4}$ were reduced by $65.40 \%, 62.39 \%$ and $61.93 \%$, respectively.

3. Since the present test was a large engineering test featuring large mass of raw material and fermentation field, it was difficult to perform repeated tests; however, the gas sampling and chemical test indicates were repeatedly tested during the test after adequate mixing of raw materials, so the experimental data are reasonable and rational.

4. Recommendations: The compost will be used in field. We did not research how compost influence gas emission during plant growth. So further researches should be conduct on how compost influences gas emissions during using process.

Acknowledgements. The study was funded by the Science and Technology Major Projects of Anhui Province (18030701190); Natural science Research Program in Universities in Anhui (KJ2018A0527); National Key R\&D Program of China (2018YFF0213502-3; 2018YFF0213501-4), Anhui Provincial Education Department's Revitalization Program for 2019 (gxyq2019061), the Dean fund project (562016Y-4686). 


\section{REFERENCES}

[1] Chen, S. L., Yuan, J., Li, G. X., He, S. Zhang, B. (2017): Combination of superphosphate and dicyandiamide decreasing greenhouse gas and $\mathrm{NH}_{3}$ emissions during sludge composting. - Transactions of the Chinese Society of Agricultural Engineering 33(6): 199-206.

[2] Fukumoto, Y., Osada, T., Hanajima, D., Haga, K. (2003): Patterns and quantities of $\mathrm{NH}_{3}$, $\mathrm{N}_{2} \mathrm{O}$, and $\mathrm{CH}_{4}$ emissions during swine manure composting without forced aeration-effect of compost pile scale. - Bioresource Technology 89(2): 109-114.

[3] Hao, X. Y., Chang, C., Larney, F., Travis, G. R. (2001): Greenhouse gas emissions during cattle feedlot manure composting. - Journal of Environmental Quality 30(2): 376386.

[4] IPCC Core Writing Team (2014): Climate change 2014. Synthesis report: Contribution of Working Groups I, II and III to the Fifth Assessment Report of the Intergovernmental Panel on Climate Change. - IPCC, Geneva.

[5] Jacinthe, P. A., Pichtel, J. R. (1992): Interaction of Nitrapyrin and Dicyandiamide with Soil Humic Compounds. - Soil Science Society of America Journal 56(2): 465-470.

[6] Jiang, T., Ma, X. G., Tang, Q., Yang, L., Li, G. (2016): Combined use of nitrification inhibitor and struvite crystallization to reduce the $\mathrm{NH}_{3}$, and $\mathrm{N}_{2} \mathrm{O}$ emissions during composting. - Bioresource Technology 217: 210-218.

[7] Jiang, T., Chang, J. L., Ma, X. G., Li, G. X. (2018): Comprehensive comparison of different nitrogen in situ conservation agents during composting. - Journal of AgroEnvironment Science 37(2): 369-375.

[8] Li, B., Wang, C. Q., Jiang, L. Q., Li, H. X., Yang, J., Yang, B. C. (2008): Effect of chemical amendments on $\mathrm{NH}_{3}$ emissions and compost maturity duriong co-composting of pig manure and straw. - Journal of Agro-Environment Science 27(4): 1653-1661.

[9] Li, X. L., Ma, J., Xu, H., Cao, J. L., Cai, Z., Yagi, K. (2008): Effect of different application time of DCD on methane and nitrous oxide emissions during rice growth period. - Acta Ecologica Sinica 28(8): 3675-3681.

[10] Lin, X. F., Li, G. X., Ren, L. M., Wang, B. (2008): Effect of $\mathrm{FeCl}_{3}$ and $\mathrm{Ca}\left(\mathrm{H}_{2} \mathrm{PO}_{4}\right)_{2}$ as amendments on reducing nitrogen loss during composting. - Journal of AgroEnvironment Science 27(4): 1662-1666.

[11] Liu, F., Zhou, L. (2015): Effects of cotton stalk wood vinegar on $\mathrm{CH}_{4}$ and $\mathrm{CO}_{2}$ emissions from cow manure composting. - Jiangsu Agricultural Sciences 43(9): 364-369.

[12] Luo, Y., Li, G., Luo, W., Schuchardt, F., Jiang, T., Xu, D. (2013): Effect of phosphogypsum and dicyandiamide as additives on $\mathrm{NH}_{3}, \mathrm{~N}_{2} \mathrm{O}$ and $\mathrm{CH}_{4}$, emissions during composting. - Biomedical and Environmental Sciences 25(7): 1338-1345.

[13] Luo, Y. M., Li, G. X., Frank, S., Wang, K., Jiang, T., Luo, M. (2012): Effects of additive superphosphate on $\mathrm{NH}_{3}, \mathrm{~N}_{2} \mathrm{O}$ and $\mathrm{CH}_{4}$ emissions during pig manure composting. - Transactions of the Chinese Society of Agricultural Engineering 28(22): 235-242.

[14] Maftoun, M., Yasrebi, J., Darbekeshti, M. (1981): Comparative phytotoxicity of nitrapyrin and ATC to several leguminous species. - Plant and soil 63(2): 303-306.

[15] Mccarty, G. W., Bremner, J. M. (1989): Inhibition of nitrification in soil by heterocyclic nitrogen compounds. - Biology \& Fertility of Soils 8(3): 204-211.

[16] Ministry of Agriculture of PRC (2017): National Development and Reform Commission. - National 13th Five-Year Plan for Rural Biogas Development and Reform of Agricultural Economics 178, Beijing.

[17] Moir, J. L., Cameron, K. C., Di, H. J. (2010): Effects of the nitrification inhibitor dicyandiamide on soil mineral $\mathrm{N}$, pasture yield, nutrient uptake and pasture quality in a grazed pasture system. - Soil Use \& Management 23(2): 111-120.

[18] Ren. L. M. (2009): Study on Mechanism of Carbon and Nitrogen Loss and Control During Composting. - China Agricultural University, Beijing. 
[19] Ren, L. M., He, Q., Li, G. X., Lu, P., Li, C. P. (2008): Effect of $\mathrm{Mg}(\mathrm{OH})_{2}$ and $\mathrm{H}_{3} \mathrm{PO}_{4}$ amendments on nitrogen conservation during simulated aerobic composting and its benefit analyses. - Transactions of the Chinese Society of Agricultural Engineering 24(4): 225-228.

[20] Sommer, S. G., Moller, H. B. (2000): Emission of greenhouse gases during composting of deep litter from pig production-effect of straw content. - Journal of Agricultural Science 134: 327-335.

[21] Subbarao, G. V., Arango, J., Masahiro, K., Hooperd, A. M., Yoshihashia, T., Andoa, K. Y., Nakaharaa, K., DeshpandeeI, S., Ortiz-Monasterioc, M. I., Ishitanib, M., Petersb, N., Chirindab, L., Wollenbergf, J. C., Latag, B., Gerard, C. S., TobitaaI, M., Raob, H. J., Iwanagaa, M. (2017): Genetic mitigation strategies to tackle agricultural GHG emissions: The case for biological nitrification inhibition technology. - Plant Science 262: 165-168.

[22] Thompson, A. G., Wagner-Riddle, C., Fleming, R. (2004): Emissions of $\mathrm{N}_{2} \mathrm{O}$ and $\mathrm{CH}_{4}$ during the composting of liquid swine manure. - Environmental Monitoring and Assessment 91(1/2/3): 87-104.

[23] Wang, Y., Li, N. N., Zhu, D. W., Zhou, W. B., Chen, Y. X., Wu, Y. P. (2018): Influence of straw pretreatment on the thermophilic composting process with pig manure. - Journal of Agro-Environment Science 37(9): 2021-2028.

[24] Wei, T. J. (2015): Mechanisms of Sorghum Secreting Biological Nitrification Inhibitors and Their Effects on Soil Ammonia-oxidizing Microorganisms. - Journal of Nanjing Agricultural University, Nanjing.

[25] Weng. J. J. (2012): Nitrogen conservation of calcium superphosphate in swine manure compost. - Journal of Anhui Agricultural Science 40(8): 4528-4529.

[26] Wolt, J., D. (2004): A meta-evaluation of nitrapyrin agronomic and environmental effectiveness with emphasis on corn production in the Midwestern USA. - Nutrient Cycling in Agroecosystems 69(1): 23-41.

[27] Wu, W. X., Li, L. J., Lu, H. H., Wang, C., Deng, H. (2012): Mechanisms of nitrous oxide emission during livestock manure aerobic composting. - Chinese Journal of Applied Ecology 23(6): 1704-1712.

[28] Xie, G. H., Bao, W. Q., Liu, J. J., An, J. (2018): An overview of researches on livestock and poultry excreta resource in China. - Journal of China Agricultural University. 23(4): 75-87.

[29] Xmb, M., Del, P. A., Merino Pestavillo, J. M. (2003): Dicyandiamide and 3,4-dimethyl pyrazole phosphate decrease $\mathrm{N}_{2} \mathrm{O}$ emissions from grassland but dicyandiamide produces deleterious effects in clover. - Journal of Plant Physiology 160(12): 1517-1523.

[30] Yang, J. I., Jia, Y. U., Jing, M. A., Xiaoping, L. I., Hua, X. U. (2011): Effect of timing of DCD application on nitrous oxide emission during wheat growing period. - Acta Ecologia Sinica 31(23): 7151-7160.

[31] Yang, Y. M, Liu, H. L., Yang, Z. F., Xi, B. D., Zhang, X. F. (2005): Methods and techniques in the control of nitrogen loss during the composting - a review. - Journal of Beijing Normal University 41(2): 213-216.

[32] Yu, Q. G., Yin, J. Z., Ma, J. W., Zou, P., Hui, L., Sun, W. C. Fu, J. R. (2014): Effects of nitrification inhibitor DMPP application in agricultural ecosystems and their influencing factors: a review. - Journal of Agro-Environment Science 33(6): 1057-1066.

[33] Zakir, H. A., Subbarao, G. V., Pearse, S. J., Gopalakrishnan, S., Ito, O., Ishikawa, T., Kawano, N., Nakahara, K., Yoshihashi, T., Ono, H., Yoshida, M. (2008): Detection, isolation and characterization of a root-exuded compound, methyl 3-(4-hydroxyphenyl) propionate, responsible for biological nitrification inhibition by sorghum (Sorghum bicolor). - New Phytologist 180(2): 442-451. 